\title{
SELECTED ISSUES OF TRUST BETWEEN TRANSACTION PARTNERS IN E-COMMERCE
}

\author{
MACIEJ CZAPLEWSKI
}

University of Szczecin, Faculty of Management and Economics of Services, POLAND

e-mail: maciej.czaplewski@wzieu.pl

\begin{tabular}{l|l}
$\begin{array}{l}\text { RECEIVED } \\
\text { JELEPTED }\end{array}$ & $\begin{array}{l}27 \text { November } 2017 \\
5 \text { January } 2018\end{array}$ \\
CLASSIFICATION & D80, F19, K24, L81 \\
ABYTSRACT & $\begin{array}{l}\text { Despite of a growing understanding of the benefits associated with e-commerce, characteristic for this form } \\
\text { of trading lack of direct contact between the sellers and the buyers, enforces a strong emphasis on building } \\
\text { customer trust. } \\
\text { The aim of this article is to present the characteristics and properties of electronic commerce and its impact } \\
\text { on customer trust in this form of trading as well as indication of activities to build and strengthen customer } \\
\text { confidence in e-commerce. } \\
\text { The article tries to verify the following hypothesis: the characteristics of e-commerce, in particular the spatial } \\
\text { distance between the seller and the buyer, points to the need to give an important role to build the trust of } \\
\text { customers to this form of trading, } \\
\text { The article layout has been subordinated to achieve the pursued objectives and to verify the hypotheses. } \\
\text { The article presents the following issues: benefits and possible risks of online trade, the impact of e-commerce } \\
\text { features on customer trust and confidence as well as selected, essential activities that serve this purpose. }\end{array}$
\end{tabular}

\section{Introduction}

E-commerce as an innovative form of trade basing on the wide use of electronic networks is distinguished by features like:

- high transparency of e-commerce related with the possibilities of acquiring in the Internet a wealth of information on e-retailers, including those posted online by these entities, 
- spatial remoteness of e-sellers and e-buyers and the lack of direct contact of these entities.

The latter feature of e-commerce makes it difficult to build customer trust, who is credited with an important role in any activity that requires interpersonal contact (Berty, 1995, pp. 236-245).

\section{Basic e-commerce benefits and risks for transaction partners}

E-commerce basing on the Internet primarily represent for e-buyers a source of rich information on the products offered on the network, their properties and prices as well as on e-retailers offering these products.

For e-retailers e-commerce means a constant reach with its offer to potential customers around the world. For e-buyers at creates the opportunity to reach interesting commercial information at any time and regardless of where they reside.

Using the Internet for buyers and sellers allows improvements in the area of products and processes. This means that e-commerce creates new market conditions having a direct impact on the market situation of e-retailers and the market situation of e-buyers. It can be concluded that the use of the Internet creates the conditions for e-retailers to:

- increase revenue, eg. due to twenty-four hours operation and due to the broad access to customers, allowing to expand the scale of operations,

- rationalize costs, eg. due to lowering the cost of maintaining the traditional retail space costs, costs of inventory and delivery costs, especially of digital products.

The literature also points to the potential risks associated with e-commerce, among which primarily exposed are the following ones (Heinemann, 2010, p. 212):

a) on the side of e-buyers:

- reluctance of a part of customers to accept the lack of physical contact with the seller,

- fear from the side of some clients against possible difficulties in case of the need to initiate a complaint procedure;

b) on the e-retailers side:

- the need to acquire competencies necessary for e-commerce,

- functioning in a highly competitive environment, where often competitors from foreign industries show up,

- the need to accept a relatively low profit margin.

Observed in some customers fear from the use of e-commerce point to the importance of building consumer confidence in this form of trading. In the process of building that trust, one can use a variety of instruments, but the primary role should be attributed to the activities of e-retailers. Given the numerous benefits that can be achieved through e-commerce for all its users, including e-retailers, they should be vitally interested in taking actions that build and strengthen customer trust in e-commerce and attracting clients to this form of trading.

\section{Developing trust in e-commerce}

Every business that requires the cooperation and contacts of various participants can proceed smoothly in conditions of existence of at least a minimal trust between them (Bleicher, 1994, p. 23; Kuczera, 2016, pp. 305306). This becomes a significant clarity in e-commerce transactions, in which: 
- the partners are spatially separated from each other,

- partners are usually a unknown, or even anonymous,

- charges for a transaction often are carried out before obtaining the ordered goods (Norris, West, 2001, p. 43; Kossecki, 2004, p. 37).

Limited partners trust within e-commerce can also be attributed to the relative newness of this form of trade and the Internet itself.

These features of e-commerce may cause to customers increased conviction of the possibility of opportunistic behavior on the part of e-retailers (Grudzewski et al., 2009, p. 129). Considering the state of matters in the literature appear definitions of trust in e-commerce. D. Kuraś and E. Paszta (2001, p. 561) confidence in e-commerce define as "customer openness on online retailer actions based on the expectation that the seller will operate in the usual way, regardless of whether the customer will benefit from the possibility of checking and controlling the online seller".

Given the indicated characteristics of e-commerce, an important element conditioning its development is the implementation of measures aimed at building and strengthening trust between users of e-commerce. Following the argument made by F. Fukuyama that a key factor in the development of the so-called new economy will be a degree of mutual trust within a widely understood society (Fukuyama, 1997, pp. 30-49), it must be assumed that in building trust between users of e-commerce essential are activities implemented in macro- and microeconomic scale.

Among the activities carried out in the macroeconomic scale, fundamental role have the developed by the competent authorities formal and legal solutions, forming a framework for e-commerce functioning. In Poland, the main regulations in this area are contained in the Act of 30 May 2014 about consumer rights. This Act introduced into national law, crucial for e-commerce, Directive of the European Parliament and Council 2011/83/EU, according to which amongst other:

- the customers have the right to withdraw from the contract within 14 days from the date of sale,

- the sellers are obliged to inform the consumer about his rights at the latest at the time of submission of the proposal to conclude the contract,

- in the case of transaction cancellation the company must return all made on its behalf payment, including the costs of delivery.

These solutions indicate that the applicable national and international law provides a strong support for e-buyers and should encourage buyers to use e-commerce. Among the macroeconomic regulation an important role in building consumer confidence in e-commerce also play regulations on the Internet and telecommunications (because the use of Internet requires access to telecommunications networks).

Significant regulatory actions concerning strictly the Internet in relation to the possible applicability of this medium in order to sell services was the introduction regulations on electronic signatures, electronic money and processing of personal data and privacy protection (Janowicz, 2000, p. 73).

At the core of such approach in the European Union policy is the issue of ensuring consumer protection. However, actions implemented at the microeconomic level a fundamental role is being played by e-retailers, who must seek to gain the trust of customers and convince customers to purchase online.

Customer confidence arouse especially those seller, whose websites include:

- transparent information about the company, including recommendations,

- precise information about the products, 
- information on applicable solutions for the privacy protection,

- solutions that provide easy navigation and certification of the website authenticity.

Provided by e-vendor wide information about himself can be an important argument for the customer when selecting a specific vendor. Information openness of an e-seller becomes almost a requirement in the conditions of an easy and inexpensive possibility of use of solutions such as comparison websites, blogs, forums and chat rooms.

In this situation, it becomes difficult to hide any blunders or any kind of fraudulent behavior of an e-seller, consisting eg. on the incomplete product descriptions, incorrect descriptions or not honouring the terms of the agreements (Peters, 2010, p. 172). An positive effect may be reached, however, by giving a presentation on their website extended information on the utility of individual goods and guarantee services provided. Seller presenting such information, which are generally not widely available, can thus obtain greater customer confidence and build an advantage over market rivals.

Undertaken measures implemented at the macroeconomic level, which are basing on the creation of increasingly sophisticated formal and legal framework regulating e-commerce, in conjunction with the development of online services to help customers acquire in-depth knowledge of e-retailers, forces them to present increasingly broader and more reliable information about them and gives a positive market effect in the form of reducing the asymmetry of information between e-commerce transaction partners especially in comparison to traditional sale, where seller generally have richer information (Fox, 2010, p. 49).

However, this points to the need for continuous improvement of sales solutions used by e-retailers, the implementation of new sales concepts and informing e-customers about their advantages conducive to further strengthening of consumer confidence in e-commerce and e-retailers.

\section{Curpent techniques of online consumers trust increase}

Properties of e-commerce associated with its reliance on the Internet and accessible information resources strongly influences the market situation of e-retailers and e-shoppers. The market position of customers using the potential of the Internet is strengthened, which enhances e-retailers the sense of an obligation to provide:

- products and services with the required quality parameters,

- favorable purchase terms.

E-sellers seeking to offer favorable conditions for the purchase do not, however, show a strong interest in the strategy of a cost leadership. This is mainly due to the fact that its use under high transparency of the market would inevitably lead to an undesirable price war. The reason may be also the fact, that in the conditions - characteristic for e-commerce - of a high ease of switching to another seller, solely a low price is often not a sufficient argument for customer retention.

In such market conditions, rises the significance of the use of offer differentiation strategies and its binding with the strategy of low prices. The legitimacy of its use should be associated primarily with high potential of offer diversification in e-commerce. Such differentiation can be achieved primarily through:

- proper selection of categories for products sold,

- the use of specialized concepts serving better customer needs and thus building a stronger bond between sellers and customers as well as in-deeper customer confidence in retailers.

According J.M. de Figueiredo (2000, p. 42) most likely to succeed in e-commerce is selling less standardized products, which are difficult to evaluate in terms of quality. 
The activities of e-retailers on the improvement of product offerings can be supported with the use of the sales concept conducive to strengthening the bounds of e-retailers with customers and deepening customer confidence in e-retailers. As particularly promising in this respect we can recognize the concepts of Mass Customization and the Long Tail (Anderson, 2004, pp. 170-174).

The concept of Mass Customization is a form of deepening the differentiation of the product offer, favoring buyers to obtain the products at most suiting their individual preferences. Sellers using this concept offer buyers alongside standard products, the ability to shape the product in a manner as nearly as possible to suit their needs.

The condition for smooth application of the concept of Mass Customization is to collect information on the individual preferences of each customer. E-sellers can achieve this goal relatively easily by installing on their websites so called product configurators, through which the customers indicate themselves their preferences.

The second previously mentioned concept - Long Tail - was established following the observation of commercial practices, which showed that a relatively large part of the product offer meets with little demand and unsold products are rarely sought after by consumers. Such products, like some books, some music, have become niche products, which traditional shops do not want to keep on the shelves (Kilian, Langner, 2010, p. 14).

Summing up, we can say, that e-commerce creates favorable conditions for its use also in marketing activities and in particular to:

- the use of so-called one-to-one marketing, which is based on establishing individual contacts with buyers and allows customization of communication as well as identification of single customers (Kowalski, 2011, p. 496),

- visibility of brands, which being a determinant of the value of the product, affect the sales volume and consumers market (Rosa, 2011, p. 371).

The smooth carrying by e-retailers of such actions serve additional differentiating of offer and strengthen their awareness on the market. This promotes the positive distinguishing from the competition, building stronger relationships with customers and deepening customer trust to those e-retailers.

\section{Conclusions}

E-commerce offers significant benefits to both - sellers and buyers. For sellers those are primarily associated with:

- creation of new business areas and the ability to take actions within this fields,

- offering solutions to improve internal production processes and customer contacts, while allowing for a better use of available resources.

On the buyers side the benefits of using e-commerce relate, in particular on:

- the possibility of transactions in the most convenient for the customer time and place,

- high transparency of e-commerce market, improving the buyers access to many relevant information about e-sellers and its offer, and thus strengthening the market position of buyers,

- saving the time required for the transaction.

In spite of a growing understanding of the benefits associated with e-commerce, distinctive for its lack of direct contact between the sellers and the buyers forces to put a strong emphasis on building customer confidence in this form of trading. A fundamental role in building this trust play:

- formal regulations concerning e-commerce and the Internet, and institutions supervising its compliance, 
- operation of e-retailers strengthening transparency of e-commerce, including their own websites,

- solutions offered by other entities of the so-called new economy sector, including those facilitating e-shoppers a comparison of offers of various e-retailers and offering customers the opportunity to comment on e-retailers behavior and their assessment.

The perceived effect of these actions is the growing acceptance of the use by citizens of modern information and communication technologies, including the Internet and the increasing acceptance of purchasing goods and services through electronic channels. It is expressed by a rapid increase in the number of Internet users, including Internet users using e-commerce. Taking into account a strong relationship between commitment and trust indicated by Tayyab Maqsood and Derek Walker (2007, p. 127) an important consequence of these changes is the increasing and more complete knowledge of customers on e-commerce, expanding their positive experience with the use of e-commerce and education, which is deepening customer confidence in this form of trading.

Positive changes taking place in the area of e-commerce market manifested by the growing demand for services in this market lead to changes on the supply side of this market, converting especially in an increase regarding the number of e-retailers and in increasing competition between them. This favorable for e-customer situation requires from e-retailers seeking and implementing new sales concepts, distinguishing them from other competitors and attracting more customers. The article indicates that the chances of such success primarily offers the use of the concept of Mass Customization and the Long Tail.

\section{References}

Anderson, Ch. (2004). The long tail. Wired, 10.

Berty, L.L. (1995). Relationship Marketing of services - Growing Interest, Emerging Perspectives. Journal of the Academy of Marketing Science, 23 (Fall).

Bleicher, K. (1995). Vertrauen als kritischer Faktor einer Bewältigung des Wandels. ZFO, 6.

Dz.U. 2014, poz. 827. Retrieved from: http://isap.sejm.gov.pl/DetailsServlet?id=WDU20140000827 (16.12.2016).

Figueiredo, de, J.M. (2000). Finding Sustainable Profitability in Electronic Commerce. Sloan Management Review, 4 (41).

Fox, A. (2010). Die Bewertung von Content-Anbietern unter besonderer Berücksichtigung von Web 2.0. Wiesbaden: Gabler Verlag/ Springer Fachmedien Wiesbaden $\mathrm{GmbH}$.

Fukuyama, F. (1997). Zaufanie. Kapitał społeczny a droga do dobrobytu. Warszawa-Wrocław: Wydawnictwo Naukowe PWN.

Grudzewski, W.M., Hejduk, I., Sankowska, A., Wańtuchowicz, M. (2009). Zarządzanie zaufaniem w przedsiębiorstwie. Kraków: Oficyna Wolters Kluwer business.

Heinemann, G. (2010). Der neue Online-Handel. Erfolgsfaktoren und Best Practices. Wiesbaden: Gabler Verlag/Springer Fachmedien Wiesbaden $\mathrm{GmbH}$.

Jankowski, J., Szałata, O. (2010). Model systemu personalizacji produkcji w organizacji wirtualnej. Zeszyty Naukowe Uniwersytetu Szczecińskiego, 598.

Janowicz, M. (2000). Nowe formy sprzedaży produktów ubezpieczeniowych (sprzedaż za pośrednictwem Internetu). In: Finanse, banki i ubezpieczenia w Polsce u progu XXI. Tom III. Ubezpieczenia. Poznań: Wydawnictwo AE w Poznaniu.

Kilian, T., Langner, S. (2010). Online-Kommunikation. Kunden zielsicher verführen und beeinflussen. Wiesbaden: Gabler Verlag/ Springer Fachmedien Wiesbaden $\mathrm{GmbH}$.

Kossecki, P. (2004). Budowa zaufania klientów w handlu elektronicznym. MBA, 3. WSPiZ L. Koźmińskiego.

Kowalski, J.A. (2011). Zmiany we współczesnej komunikacji marketingowej w warunkach społeczeństwa informacyjnego. Zeszyty Naukowe Uniwersytetu Szczecińskiego, 651.

Kuczera, K. (2016). Wykorzystanie metody AHP w identyfikacji preferencji decydentów firm odnośnie modeli biznesu - wnioski z badań, Ekonomiczne Problemy Usług, 122. 
Kuraś, D., Paszta, E. (2011). Kształtowanie relacji z klientami poprzez zaufanie we-komunikacji marketingowej. In: A. Jaki, J. Karczmarek, T. Rojek (eds.), Restrukturyzacja. Teoria i praktyka w obliczu nowych wyzwań. Kraków: Wydawnictwo: Fundacja UE w Krakowie. Maqsood, T., Walker, D. (2007). Extending the „knowledge advantage” creating learning chains. The Learning Organization, 14 (2). Norris, M., West, S. (2001). E-biznes. Warszawa: Wydawnictwa Komunikacji i Łączności.

Peters, R. (2010). Internet-Ökonomie. Berlin Heidelberg: Springer Verlag.

Rosa, G. (2011). Wartość reputacji i moc marki na rynku usług telekomunikacyjnych na podstawie rankingu marek polskich. Zeszyty Naukowe Uniwersytetu Szczecińskiego, 650.

Cite this anticle aS: Czaplewski, M. (2018). Selected issues of trust between transaction partners in e-commerce. European Journal of Service Management, 1 (25), 49-55. DOI: 10.18276/ejsm.2018.25-06. 